\title{
Pretreatment with A Small-Molecule Tumor Necrosis Factor-Alpha (TNF- $\alpha$ ) Inhibitor, UTL-5g, Reduced Radiation-Induced Acute Liver Toxicity in Mice
}

\author{
Jiajiu Shaw ${ }^{1}$, Jie Zhang ${ }^{2}$, Ming Zhang ${ }^{2}$, Frederick Valeriote ${ }^{3}$, Ben Chen $^{4}$
}

${ }^{1} 21^{\text {st }}$ Century Therapeutics, Inc., Ferndale, MI 48220, USA

${ }^{2}$ Department of Radiation Oncology, University of Michigan, Ann Arbor, MI 48109, USA

${ }^{3}$ Department of Internal Medicine, Henry Ford Health System, Detroit, MI 48202, USA

${ }^{4}$ Department of Internal Medicine, Wayne State University School of Medicine, Detroit, MI 48201, USA

Corresponding author:

J. Shaw, Ph.D.

$21^{\text {st }}$ Century Therapeutics, Inc..

1366 Hilton Rd., Ferndale

Michigan 48220, USA

Telephone: 734-330-6052

E-mail: jshaw@21-cti.com

Received: 15 November 2011; | Revised: 13 December 2011; | Accepted: 22 December 2011

\begin{abstract}
Radiation-induced liver toxicity is a major limitation to the use of radiation in the treatment of intrahepatic cancers. The purpose of this study was to evaluate the potential radioprotective effect of a smallmolecule tumor necrosis factor alpha (TNF- $\alpha$ ) inhibitor, UTL-5g, against radiation-induced acute liver injury. Mice were pre-treated by i.p. injection with UTL-5g and control vehicle one hr prior to liver irradiation at $15 \mathrm{~Gy}$. Blood and liver were collected $2 \mathrm{hr}$ after irradiation and analyzed for levels of aspartate aminotransferase (AST) and alanine aminotransferase (ALT) activities in serum and TNF- $\alpha$ in liver tissue extracts. Both AST and ALT in serum and TNF- $\alpha$ in liver induced by irradiation were significantly reduced by UTL-5g in a drug dose-dependent manner. The reductions of AST, ALT and TNF- $\alpha$ appeared to correlate with the reduction of liver apoptosis detected by terminal deoxynucleotidyl transferase dUTP nick end labeling (TUNEL) assay. A radiation dose escalation study (5, 15 and 25 Gy) showed that UTL-5g at 60 $\mathrm{mg} / \mathrm{kg}$ was effective as a radioprotective agent at 5 and $15 \mathrm{~Gy}$; the protection was only modest at $25 \mathrm{~Gy}$. In summary, our results suggest that the TNF- $\alpha$ inhibitor, UTL-5g, is potentially radioprotective against acute phase of radiation-induced liver injury.
\end{abstract}

Keywords: liver, radiation, radioprotective, TNF- $\alpha$, UTL-5g.

\section{Introduction}

While radiotherapy is an important modality for malignant hepatoma, its use is limited by radiation-induced liver toxicity in which patients inevitably suffer from liver damage and function failure [1]. Radiation-induced toxicity results from a series of pathological changes at both cellular 
and biochemical levels, which include DNA damage, early cell apoptosis, inflammation and, ultimately, radiation-induced latent fibrosis and loss of liver function. Many strategies and compounds have been studied for their protective effects against radiation [2-4]. Ethyol® (amifostine) is the only radioprotector approved by the FDA to reduce xerostomia associated with radiotherapy of head-and-neck cancer. Presumably, amifostine works as an antioxidant that scavenges free radicals [5], but other mechanisms such as DNA repair have also been proposed $[6,7]$. While amifostine reduces normal organ damage caused by radiation $[4,6,8]$, it does have serious adverse effects including nausea and vomiting, as well as transient hypotension [9, 10].

In general, radioprotective agents fall into the following classes: 1) thiol compounds [11-13]; 2) nitroxides $[14,15]$; 3) polysaccharides [12]; 4) oligonucleotides, such as TNF receptor antisense oligonucleotides (ASO) [3, 16]; and 5) other potential radioprotective agents, such as melatonin, vitamins, and pharmacological inhibitors of cyclin-dependent kinases [11, 17, 18].

It is known that TNF- $\alpha$ and other inflammatory cytokines are up-regulated in various organs following radiation exposure [3, 19]. Numerous studies have shown that excessive amounts of TNF- $\alpha$ can cause cell apoptosis, resulting in injury of normal liver tissues [20,21]. TNF receptor 1 (TNFR1) ASO was suggested to be a potential treatment to prevent radiationinduced liver injury. Huang et al. reported that 10 Gy irradiation transiently increased liver TNF- $\alpha$ levels by $\sim 50 \%$ at $2 \mathrm{hr}$ in mice as compared to non-irradiated control, and pre-treating mice with TNFR1 ASO was effective in preventing the liver damage [3]. In a similar study, Zhang et al. showed that inhibition of TNF- $\alpha$ pathway with TNFR1 ASO reduced radiation-induced lung injury without compromising tumor response [16].

Since down-regulation of TNFR1 with targetspecific ASO showed positive results in liver radioprotection, we hypothesize that lowering the elevated TNF- $\alpha$ production induced by radiation may be a potential route of liver radioprotection. Previously, we have synthesized a series of small molecule carboxamidyl isoxazoles, UTL-series, which are inhibitory to TNF- $\alpha$ production [2224]. Here, we screened three of these TNF- $\alpha$ inhibitors (Fig. 1) and found that one of them, UTL- $5 \mathrm{~g}$, was the most potent liver radioprotector against early phase liver toxicity.

\section{Methods and materials}

\subsection{Animals}

Male C57BL/6 mice (4-6 weeks, 20-25 g body weight) were obtained from the Jackson Laboratories (Bar Harbor, Maine). All animal experiments were conducted in full accordance with the Institutional Animal Care and Use Committee (IACUC) Guidelines for the care and management of laboratory animals.

\subsection{Materials}

UTL-5b, -5d, and -5g (purity > 99\%) (Fig. 1) were obtained from Unitech Pharmaceuticals, Inc. (Ann Arbor, MI). Individual compounds were prepared as stock solutions at $40 \mathrm{mg} / \mathrm{mL}$ in DMSO. Equal volume of the stock solution and a premixed solvent (cremophor EL:propylene glycol $4: 6 \mathrm{v} / \mathrm{v}$ ) or ethanol were mixed and then added with saline individually to make a suspension in DMSO/(cremophor:propylene glycol 6:4)/saline 5:5:90 v/v (vehicle I) or in DMSO/ethanol/saline 5:5:90 v/v (vehicle II) prior to injection. AlphaMEM was obtained from MediaTech (Manassas, VA). TUNEL staining kit was obtained from Roche Applied Science (Indianapolis, IN).

\subsection{Radiation protection study}

To test the radioprotective effect, animals were treated by i.p. injection with $0.3 \mathrm{~mL}$ of control vehicle or selected compounds one hr prior to liver irradiation using a Philips RT 250 orthovoltage unit machine that produces $250 \mathrm{kV}$ $\mathrm{X}$-ray at $1 \mathrm{~Gy} / \mathrm{min}$. Conscious mice were placed in plastic restrainer and the liver portion was centered in a $2 \times 4 \mathrm{~cm}$ exposure field with other abdominal structures and the body protected by a customized lead shielding. Control mice were subjected to similar procedures without receiving the radiation dose. Blood (by cardiac puncture) and liver were collected at $2 \mathrm{hr}$ after radiation. Harvested serum and tissue were stored at $-70^{\circ} \mathrm{C}$ until needed for biochemical and ELISA tests. 


\subsection{Liver enzyme activities}

Radiation-induced liver damage was assessed by measuring blood liver enzyme activities. Serum AST and ALT activities were assessed using a commercial assay kit according to the manufacturer's instruction (Biotron Diagnostics, Inc., Hemet, $\mathrm{CA}$ ). Ten $\mu \mathrm{L}$ of each serum sample were used for each test. Data were presented as units per liter (Unit/L) \pm S.D.

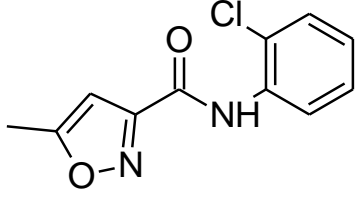

UTL-5b

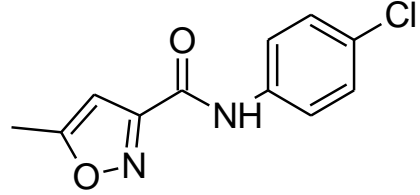

UTL-5d

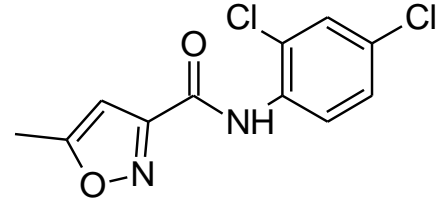

UTL-5g

Figure 1. Structures of three small-molecule TNF- $\alpha$ inhibitors.

\subsection{Determination of TNF- $\alpha$ levels in liver extracts}

For measurement of liver TNF- $\alpha$, livers were first perfused with $20 \mathrm{~mL}$ of saline through the portal vein, then minced into small chunks (8 $\mathrm{mm}^{3}$ ) and homogenized in $150 \mu \mathrm{L}$ of PBS containing protease inhibitors using a Dounce homogenizer. The tissue homogenates were then subjected to centrifugation at $6,000 \mathrm{rpm}(3,500 \mathrm{x}$ g) for $5 \mathrm{~min}$ to remove tissues debris. Supernatants from liver tissue extracts were further diluted with ELISA reagent diluent (1:50) and the diluted supernatants (100 $\mu \mathrm{L} /$ well) were assayed for TNF$\alpha$ using a commercial ELISA kit according to manufacturer's recommendation (R \& D Systems, Minneapolis, MN). Each sample was measured in triplicate and TNF- $\alpha$ concentration (pg/mg tissue protein) was calculated based on a standard curve and the total amount of tissue protein in the supernatant.

\subsection{Terminal deoxynucleotidyl transferase dUTP nick end labeling (TUNEL) assay}

Radiation-induced liver cell death was assessed by measuring DNA strand breaks using an in situ TUNEL staining approach (Roche Applied Science, Indianapolis, IN). Briefly, liver tissue were collected, cryopreserved and sectioned. The tissue slides were fixed in $4 \%$ paraformaldehyde for 10 min followed by washing in PBS. After permeabilization in a solution of
$0.1 \%$ Triton-X-100 and $0.1 \%$ sodium citrate, liver tissue sections were labeled with $25 \mu \mathrm{L}$ of TUNEL reaction mixture containing 1:2 dilution of enzyme at $37^{\circ} \mathrm{C}$ in a humidified chamber for 2 hr. Fluorescence signals positive for TUNEL staining were counted from 5 randomly selected areas under a fluorescence microscope (40 x).

\subsection{Statistics}

Power analysis was performed before each animal study and a sample size of 4 mice per group was determined to have a $80 \%$ power of detecting a mean difference of 11.70 with a significance level of 5\% (two sided). Values are shown as the means \pm standard deviation (S.D.)

\section{Results}

\subsection{Radioprotective effects of UTL-5b, -5d, and} $-5 \mathrm{~g}$

In a preliminary study, three UTL compounds $(5 \mathrm{~b}, 5 \mathrm{~d}$ and $5 \mathrm{~g}$ ) were examined for their radioprotective effect in C57BL/6 mice. One $\mathrm{hr}$ prior to liver irradiation (15 Gy), animals were treated with the test compounds by i.p. injection (30 $\mathrm{mg} / \mathrm{kg}$ ). Two hr later, the animals were sacrificed and serum AST and ALT enzyme activities were determined. As shown in Fig. 2, pretreatment of the animals with these compounds lowered serum AST and ALT levels induced by irradiation. Among them, UTL-5g was the most 
effective in lowering both AST and ALT enzyme activities and was selected for further experiments.

During the preliminary study, it was found unexpectedly that the vehicle used (vehicle I), DMSO/(Cremophor/propylene glycol)/saline, was associated with some liver toxicity as indicated by the moderate increase of serum AST and ALT activities in animals treated with vehicle alone (Fig. 3). Therefore, a different vehicle (vehicle II), $\mathrm{DMSO} / \mathrm{EtOH} / \mathrm{saline}(5 / 5 / 90 \mathrm{v} / \mathrm{v})$ was tested and compared to that of vehicle I. As shown in Fig. 3, injection with vehicle I did show some liver toxicity in mice. In contrast, treatment with DMSO/EtOH/saline (5/5/90 v/v) vehicle showed essentially no toxicity and was selected as the desired vehicle for preparing UTL-5g solution in subsequent studies.

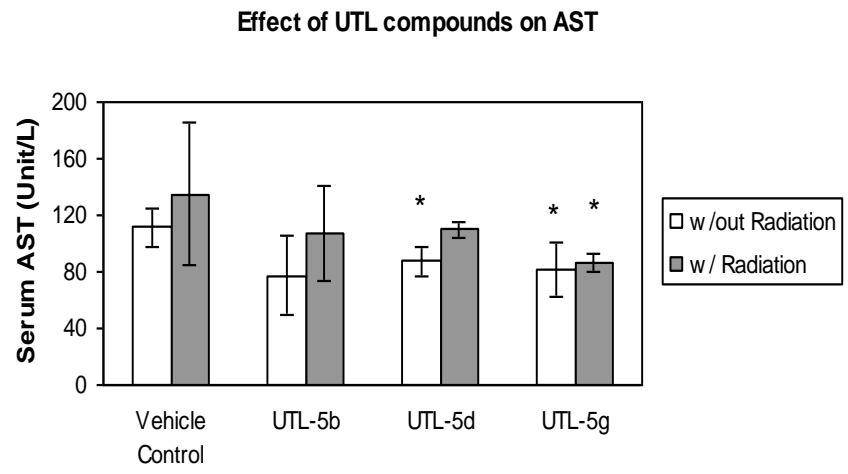

Effect of UTL compounds on ALT

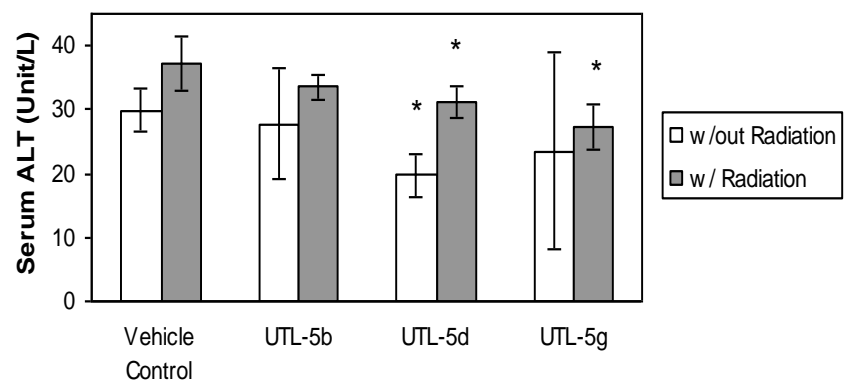

Figure 2. C57BL/6 male mice were treated with UTL$5 \mathrm{~b},-5 \mathrm{~d}$, and $-5 \mathrm{~g}$ each in $0.3 \mathrm{~mL}$ vehicle (Vehicle I) by i.p. injection $(30 \mathrm{mg} / \mathrm{kg}) 1 \mathrm{hr}$ prior to liver irradiation with 15 Gy. Control mice received vehicle only followed by irradiation. Serum was obtained at $2 \mathrm{hr}$ after irradiation and assayed for AST and ALT activities. Data are means \pm standard deviation (S.D.) * indicates $\mathrm{p}<0.05$ as compared to Vehicle $\mathrm{I}, \mathrm{n}=4$.

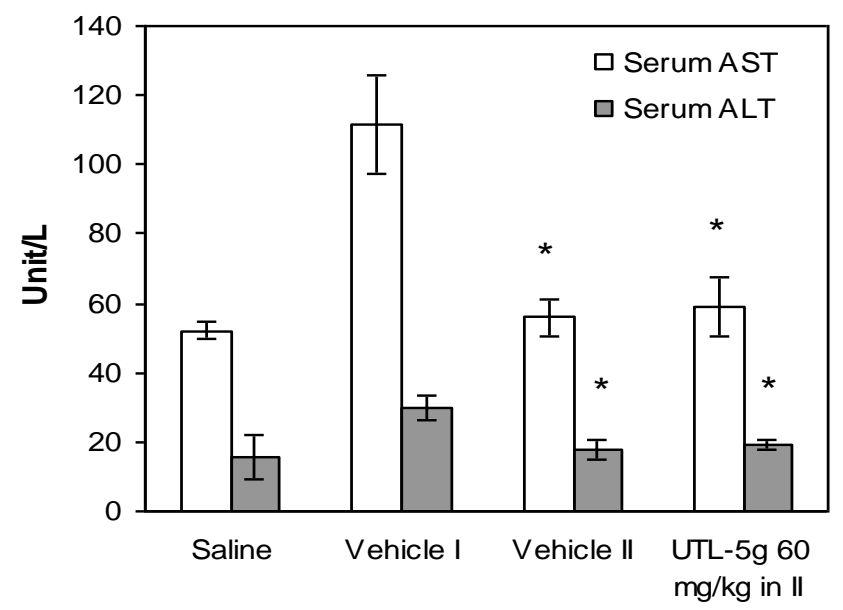

Figure 3. Comparison of the liver toxicity by two different vehicles without radiation. All treatments were made by i.p. injection. Vehicle I: DMSO/(Cremophor:PG)/saline 5/5/90 v/v. Vehicle II: $\mathrm{DMSO} / \mathrm{EtOH} / \mathrm{saline} 5 / 5 / 90 \mathrm{v} / \mathrm{v}$. *Significantly reduced AST or ALT levels as compared to Vehicle I ( $p<0.05$, $\mathrm{n}=4)$.

\subsection{Dose-dependent radioprotective effect of UTL-5g}

Based on the preliminary studies, UTL-5g was selected for dose-dependent radioprotective studies. In this study, animals were treated with increasing doses of UTL-5g (from 0 to $60 \mathrm{mg} / \mathrm{kg}$ ) one $\mathrm{hr}$ prior to liver irradiation (15 Gy). Two hr after irradiation, animals were sacrificed and serum AST/ALT enzyme activities and liver TNF$\alpha$ levels were determined. As shown in Fig. 4, liver irradiation at 15 Gy significantly induced serum AST/ALT activities (increased from 52 to $135 \mathrm{Unit} / \mathrm{L}$ and 15 to $29 \mathrm{Unit} / \mathrm{L}$, respectively). Pretreatment of UTL-5g one hr before irradiation significantly reduced serum AST/ALT activities in a drug dose-dependent manner $(\mathrm{p}<0.05$, paired $\mathrm{t}$ test). For animals pre-treated with UTL-5g at 30 $\mathrm{mg} / \mathrm{kg}$, AST/ALT activity levels were lowered from 135/29 to 89/22 Unit/L, and those pre-treated with UTL-5g at $60 \mathrm{mg} / \mathrm{kg}$, AST/ALT levels were reduced from 135/29 to 74/19 Unit/L, respectively. However, treatment with high dose of UTL-5g (60 mg/kg) alone slightly increased the levels of both AST and ALT enzyme activities in animals without irradiation (Fig. 4). 

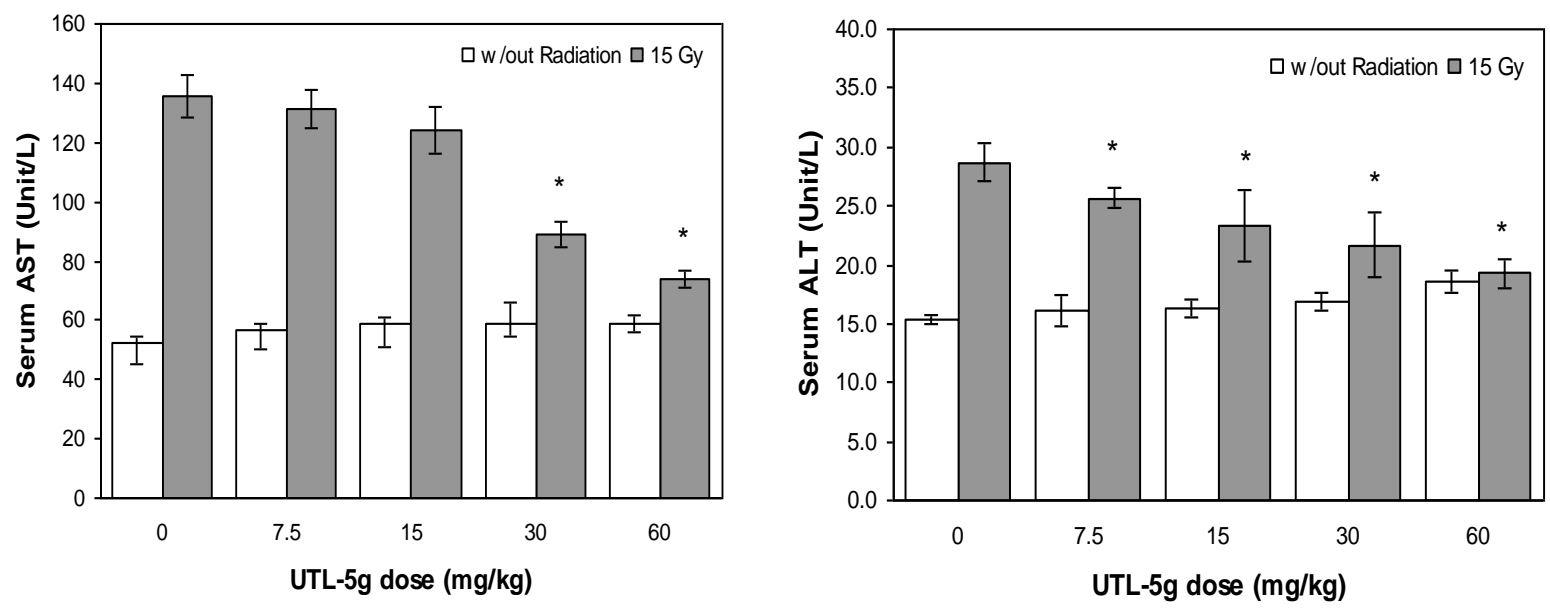

Figure 4. Drug dose dependent radioprotection of liver by UTL-5g. Mice were treated with various doses of UTL-5g $(0,7.5,15,30$, and $60 \mathrm{mg} / \mathrm{kg}$, i.p. $) 1 \mathrm{hr}$ prior to liver radiation with $15 \mathrm{~Gy}$. Serum was obtained at $2 \mathrm{hr}$ after irradiation and assayed for AST and ALT activities. Data shown are means \pm standard deviation (S.D.) *Significantly reduced AST or ALT levels as compared to irradiated mice treated with vehicle only, $p<0.05(n=4)$. Two-tailed paired t-Test showed $\mathrm{p}<0.05$.

As shown in Fig. 5, TNF- $\alpha$ levels in liver extracts from irradiated mice (15 Gy) were increased by $56 \%$ compared with non-irradiated control animals (from 37.6 to $58.9 \mathrm{pg} / \mathrm{mg}$ tissue protein). Likewise, pre-treatment of animals with UTL-5g significantly reduced liver TNF- $\alpha$ levels by $20 \%$ and $29 \%$ at $30 \mathrm{mg} / \mathrm{kg}$ and $60 \mathrm{mg} / \mathrm{kg}$, respectively.

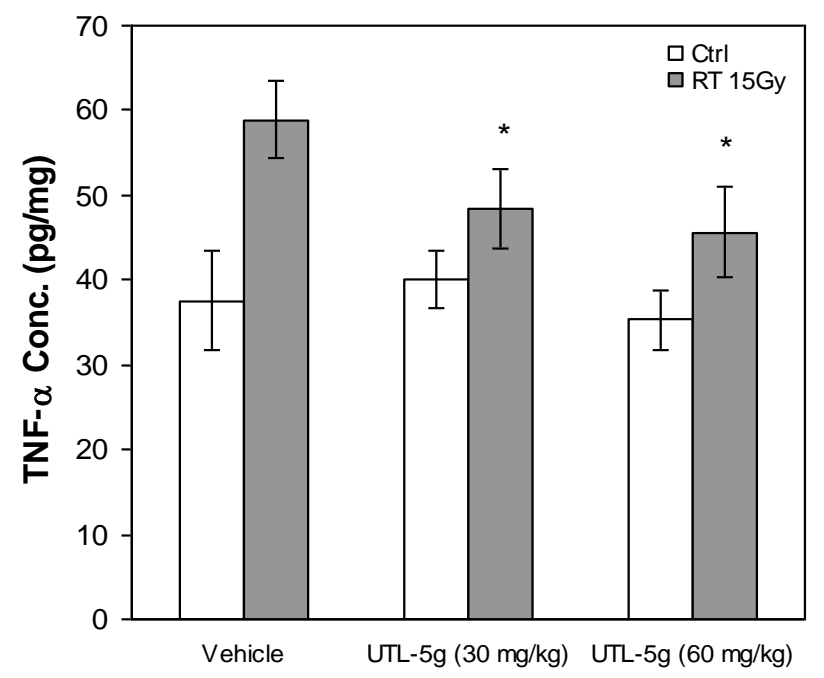

Figure 5. Drug dose-dependent reduction of TNF- $\alpha$. Mice were treated individually with $0.3 \mathrm{~mL}$ each of UTL-5g preparations i.p. $1 \mathrm{hr}$ prior to liver irradiation at 15 Gy. Liver TNF- $\alpha$ levels were analyzed by standard ELISA methodology. TNF- $\alpha$ levels in irradiated liver (at 15 Gy) were increased by $56 \%$ (from 37.6 to $58.9 \mathrm{pg} / \mu \mathrm{g}$ ) and the pretreatment by UTL-5g significantly reduced TNF- $\alpha$ by $20 \%$ and $29 \%$ at $30 \mathrm{mg} / \mathrm{kg}$ and $60 \mathrm{mg} / \mathrm{kg}$, respectively $(* \mathrm{p}<0.05$, 2tailed paired t-Test comparing treated and untreated for both $30 \mathrm{mg} / \mathrm{kg}$ and $60 \mathrm{mg} / \mathrm{kg}$ groups, $\mathrm{n}=4$ ).

\subsection{Radiation doses and radioprotective effect of UTL-5g}

Next, we investigated the radioprotective effect of UTL-5g with increased irradiation doses. In this study, animals were pre-treated with UTL$5 \mathrm{~g}$ at $60 \mathrm{mg} / \mathrm{kg}$ and randomly divided into 4 groups. One hr later, they were subjected to liver irradiation at $0,5,15$ and $25 \mathrm{~Gy}$. Consistent with the previous study, pretreatment with UTL-5g at $60 \mathrm{mg} / \mathrm{kg}$ was radioprotective against $15 \mathrm{~Gy}$ as evidenced by the reduction of serum AST activity (103.0 vs. 159.8 Unit/L in UTL-5g and in control vehicle groups, respectively) and ALT activity (17.8 vs. 32.3 Unit/L in UTL-5g and in control vehicle groups respectively) (Fig. 6). However, only moderate protection was observed in group of mice irradiated with 25 Gy. At lowest irradiation dose $(5 \mathrm{~Gy})$ used in this study, both AST and ALT levels were slightly elevated by 
radiation and reduced by UTL-5g but not statistically significant.
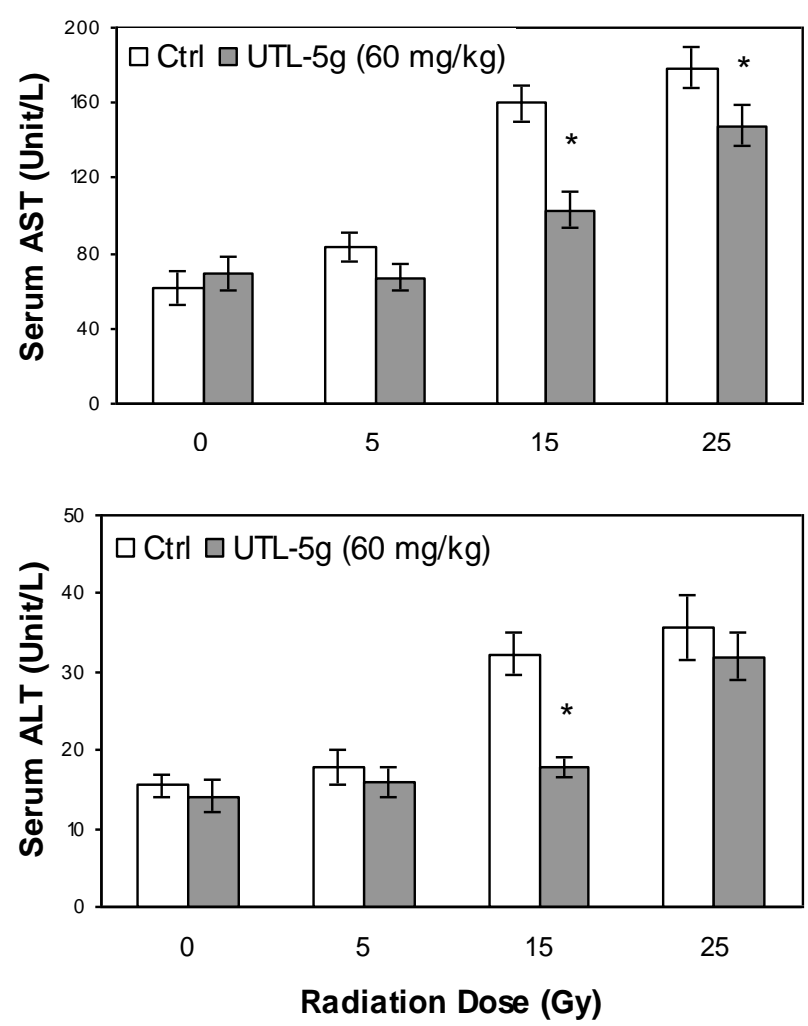

Figure 6. Radiation dose escalation and radioprotection by UTL-5g. Mice were pre-treated with UTL-5g $(60 \mathrm{mg} / \mathrm{kg}$, i.p. $)$ at $1 \mathrm{hr}$ prior to radiation dose escalation $(0,5,15$, and $25 \mathrm{~Gy})$. Serum was harvested at $2 \mathrm{hr}$ after injections and was subjected to AST/ALT measurements as described in Methods. Results were compared to control mice received control vehicle. Data are means \pm standard deviation $(* \mathrm{p}<0.05,2$ tailed paired t-Test comparing treated and untreated groups, $n=4)$.

\subsection{TUNEL assay for apoptotic liver cells}

To further analyze the radioprotective effect of UTL-5g, we examined the number of liver apoptotic cells by in situ TUNEL staining. At the end of treatment, liver tissue sections were prepared, fixed and stained with TUNEL staining for apoptotic cells. There were "spontaneous" apoptotic liver cells in control animals as detected by TUNEL staining (20/five random fields), approximately $0.2 \%$ of total liver cells. The numbers of TUNEL positive cells in the tissue sections were markedly increased (82/five random fields) (> 4-fold) by 15 Gy of radiation as compared to non-irradiated controls (Fig. 7). The radioprotective effect of UTL-5g was drug dosedependent. At the lowest dose of UTL-5g (7.5 $\mathrm{mg} / \mathrm{kg}$ ), there was no significant protective effect. However, for higher doses, the numbers of TUNEL positive cells induced by irradiation in the liver were significantly reduced from 4.1 to 3.3 , 1.8, and 1.4-fold for animals treated with 15, 30, and $60 \mathrm{mg} / \mathrm{kg} \quad$ UTL-5g, respectively. Unexpectedly, treatment with UTL-5g alone at the higher doses (30 and $60 \mathrm{mg} / \mathrm{kg}$ ) also slightly increased the number of apoptotic cells in the liver tissue section from non-irradiated animals.
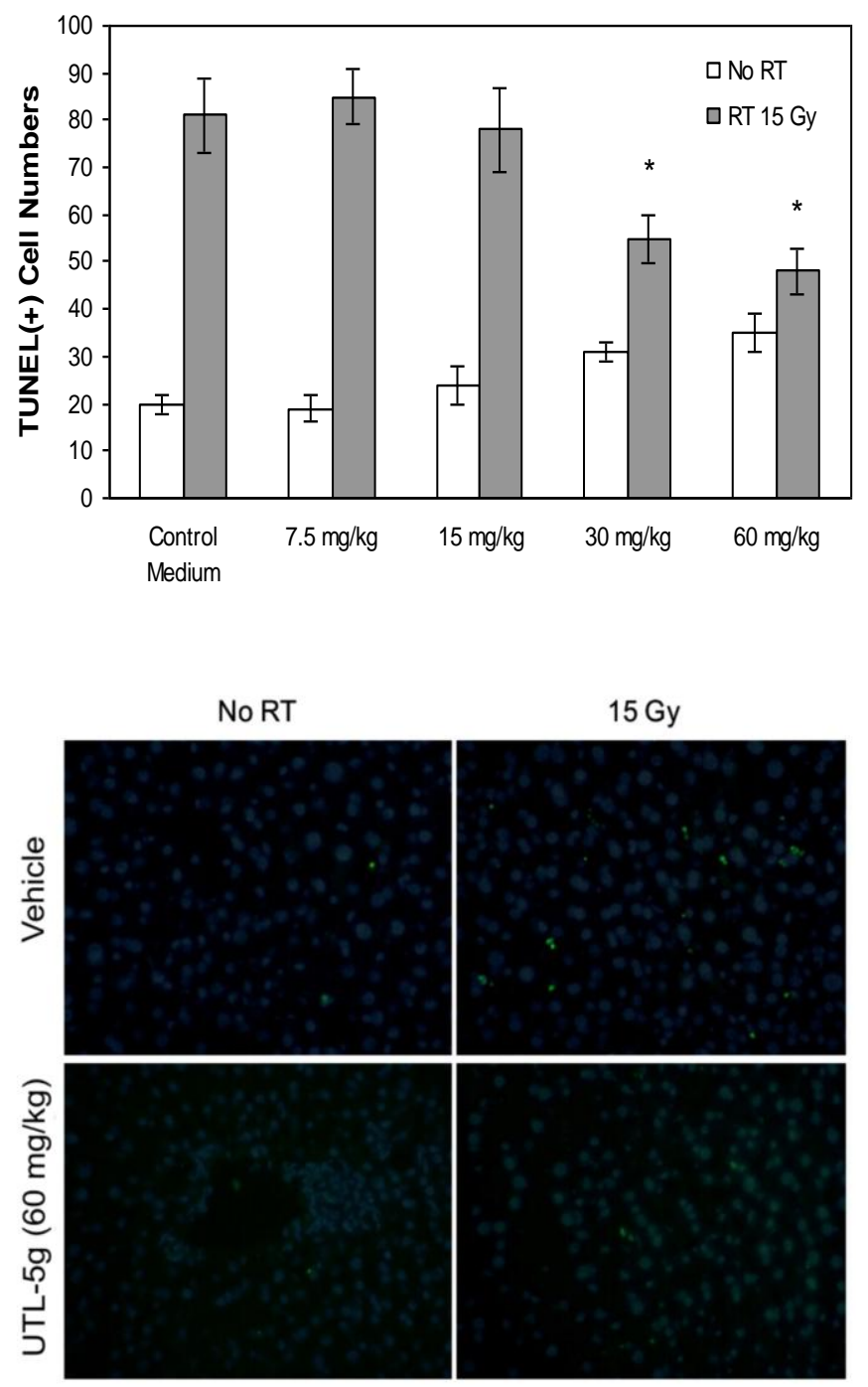

Figure 7. UTL-5g reduced radiation-induced liver apoptosis measured by TUNEL staining. Mice were pre-treated with various doses of UTL-5g $(7.5,15,30$, and $60 \mathrm{mg} / \mathrm{kg}$, i.p.) or control vehicle at $1 \mathrm{hr}$ prior to 
liver radiation with 15 Gy. Liver tissues were harvested at $2 \mathrm{hr}$ after radiation for cryosections and were subjected to TUNEL staining. Positive cells were counted under fluorescent microscope $(40 \mathrm{x})$ from 5 randomly selected fields and were plotted as averages. *TUNEL $(+)$ cell numbers were significantly reduced relative to vehicle $(\mathrm{p}<0.05, \mathrm{n}=4)$ (top). Representative liver sections showing TUNEL positive cells (green) counter-stained with DIPA (4'-6diamidino-2-phenylindole) for nuclei under fluorescent microscope (40x) (bottom). RT: radiation treatment.

\section{Discussion}

Earlier studies have pointed to a close relationship between the levels of TNF- $\alpha$ and radiation-induced apoptosis [3, 16]. To further investigate the mechanistic connections during these early events, we examined the levels of TNF- $\alpha$ and liver cell apoptosis in irradiated mice. Irradiation of the animals with 15 Gy markedly increased the number of apoptotic liver cells by more than four-fold within two hr. At the same irradiation dose, the levels of liver TNF- $\alpha$ production increased $56 \%$ compared to nonirradiated group (Fig. 5). It is not known why the $\%$ increase of liver TNF- $\alpha$ level $(56 \%)$ is much lower than the \% increase of liver apoptotic cells (> four-fold) following irradiation. Conceivably, other inflammatory cytokines and/or mechanisms such as reactive free radical are also operative in causing apoptosis in liver. Another possible explanation is that locally produced $\mathrm{TNF}-\alpha$ following irradiation is rapidly removed and dissipated into circulation. Nonetheless, pretreatment with UTL-5g could effectively lower the levels of both TNF- $\alpha$ and number of apoptotic liver cells in a drug dose-dependent manner $2 \mathrm{hr}$ after irradiation, indicating that TNF- $\alpha$ is indeed an important factor responsible for liver cell apoptosis. A quantitative relationship between liver apoptotic cells and radiation-induced liver acute toxicity as defined by liver enzyme activities, however, remains to be established.

The cell types responsible for $\mathrm{TNF}-\alpha$ production following irradiation are not known at present. A recent study suggests that Kupffer cells (liver macrophages) may be the primary sources responsible for the production of TNF- $\alpha$ in situ [3]. We have shown that UV irradiation can trigger epithelial cells to release $\mathrm{TNF}-\alpha$ in vitro [23]. Other cell types such as fibroblasts and epithelial cells in the liver can produce $\mathrm{TNF}-\alpha$ in response to irradiation as had been shown previously in skin cells $[25,26]$. Thus, it is likely that multiple cell types are responsible for TNF- $\alpha$ production in the liver.

Our data and others established the feasibility of radioprotection by inhibiting the TNF- $\alpha$ pathway. However, it remains to be determined if inhibition of TNF- $\alpha$ pathway by UTL-5g may cause adverse effects on the therapeutic efficacy by radiation. In a previous study, Zhang et al. showed that inhibition of TNFR by either genetic deficiency or ASO could protect lung function without compromising lung tumor sensitivity to radiation [16]. We recently reported that UTL-5g treatment did not attenuate the anti-tumor effect of cisplatin but enhanced the therapeutic efficacy of cisplatin in a SCID mouse model inoculated with human HCT-15 tumor cells [24]. Treatment with TNF- $\alpha$ inhibitors, such as UTL-5g, therefore is justified as a protective measure during either chemotherapy or radiation treatment. These findings also suggest that aberrant TNF- $\alpha$ production induced by radiation and anti-cancer agents is in fact clinically detrimental to the overall therapeutic efficacy.

Radiation dose escalation experiments showed that the radioprotection by UTL-5g is less effective when the radiation dose was increased to $25 \mathrm{~Gy}$, suggesting that the transient liver damaged induced by high dose irradiation may have reached the maximal protection capability of UTL-5g as currently formulated and administered. Giving that multiple factors and mechanisms are likely involved in causing liver toxicity and pathologic changes, a combined treatment using various radioprotectors with different mechanisms of action may be essential to achieving optimal radioprotective effect. The current study focused on the early events of radiation-induced liver acute toxicity. Thus, radioprotective effect of UTL-5g for long-term hepatic damage is not known at present. Recent studies suggest that much of the delayed damage may be caused by aberrant and prolonged production of wound healing proinflammatory cytokines including TNF- $\alpha$ in situ [2, 16, 19]. Since the production of these 
cytokines is regulated by identical and interrelated inflammatory signaling pathways, it is reasonable to speculate that UTL-5g may have long-term radioprotective effect as well, but further studies are needed to investigate the long-term effect of UTL-5g. UTL-5g is very tolerable in animal acute toxicity test and can be administered orally at higher dose for extended period. In a previous study, we showed that UTL-5g has a LD $_{50}$ of $>2,000 \mathrm{mg} / \mathrm{kg}$ [24]. Future studies on the effect of UTL-5g on the levels of wound healing cytokines such as platelet-derived growth factor, transforming growth factor- $\beta$ and fibroblast growth factor in delayed liver damage may provide crucial insights into the potential mechanistic connections.

\section{Acknowledgments}

This work was supported by SBIR grant 1 R43 CA117033 from the National Cancer Institute, National Institutes of Health, Department of Health and Human Services, USA.

Abbreviations: ASO, antisense oligonucleotide; AST, aminotransferase; ALT, alanine aminotransferase; TNF- $\alpha$, tumor necrosis factoralpha; TUNEL, terminal deoxynucleotidyl transferase dUTP nick end labeling.

\section{References}

1. Lawrence, T.S.; Robertson, J.M.; Anscher, M.S.; Jirtle, R.L.; Ensminger, W.D.; Fajardo, L.F. Hepatic toxicity resulting from cancer treatment, Int J Radiat Oncol Biol Phys., 1995, 31,1237-1248. DOI: 10.1016/0360-3016(94) 00418-K

2. Du, S.-S.; Qiang, M.; Zeng, Z.-C.; Zhou, J.; Tan, Y.-S.; Zhang, Z.-Y.; Zeng, H.-Y.; ZhongShan, L. Radiation-Induced Liver Fibrosis Is Mitigated by Gene Therapy Inhibiting Transforming Growth Factor-[beta] Signaling in the Rat, Int J Radiat Oncol Biol Phys., 2010, 78,1513-1523. DOI: 10.1016/j.ijrobp. $\underline{2010.06 .046}$
3. Huang, X.W.; Yang, J.; Dragovic, A.F.; Zhang, H.; Lawrence, T.S.; Zhang, M. Antisense oligonucleotide inhibition of tumor necrosis factor receptor 1 protects the liver from radiation-induced apoptosis, Clin Cancer Res., 2006, 12,2849-2855. DOI: 10.1158/1078-0432.CCR-06-0360

4. Symon, Z.; Levi, M.; Ensminger, W.D.; Smith, D.E.; Lawrence, T.S. Selective radioprotection of hepatocytes by systemic and portal vein infusions of amifostine in a rat liver tumor model, Int J Radiat Oncol Biol Phys., 2001, 50,473-478. DOI: 10.1016/S0360-3016(01) 01522-X

5. Grdina, D.J.; Murley, J.S.; Kataoka, Y.; Baker, K.L.; Kunnavakkam, R.; Coleman, M.C.; Spitz, D.R. Amifostine induces antioxidant enzymatic activities in normal tissues and a transplantable tumor that can affect radiation response, Int J Radiat Oncol Biol Phys., 2009, 73,886-896.

DOI: 10.1016/j.ijrobp.2008.10.061

6. Hirschel-Scholz, S.; Paunier, L.; Bonjour, J.P. Interference of WR-2721 with magnesium metabolism: mechanism of action, Miner Electrolyte Metab. 1988, 14,114-120.

7. van Beek, M.E.; Doak, R.L.; Sigdestad, C.P.; Grdina, D.J. Pathological effects of the radiation protector WR-151327 in mice, Radiat Res., 1990, 124,79-84. DOI: $10.2307 / 3577698$

8. Rasey, J.S.; Nelson, N.J.; Mahler, P.; Anderson, K.; Krohn, K.A.; Menard, T. Radioprotection of normal tissues against gamma rays and cyclotron neutrons with WR2721: LD50 studies and 35S-WR-2721 biodistribution, Radiat Res., 1984, 97,598-607. DOI: $10.2307 / 3576151$

9. Mabro, M.; Faivre, S.; Raymond, E. A RiskBenefi Assessment of Amifostine in Cytoprotection, Drug Safety, 1999, 5,367-387.

10. Rades, D.; Fehlauer, F.; Bajrovic, A.; Mahlmann, B.; Richter, E.; Alberti, W. Serious adverse effects of amifostine during radiotherapy in head and neck cancer patients, Radiother Oncol., 2004, 70,261-264. DOI: $\underline{10.1016 / \text { j.radonc.2003.10.005 }}$ 
11. Srinivasan, V.; Weiss, J.F. Radioprotection by vitamin $\mathrm{E}$ : injectable vitamin $\mathrm{E}$ administered alone or with WR-3689 enhances survival of irradiated mice, Int J Radiat Oncol Biol Phys., 1992, 23,841-845. DOI: 10.1016/0360-3016 (92)90657-4

12. Patchen, M.L.; MacVittie, T.J.; Solberg, B.D.; D'Alesandro, M.M.; Brook, I. Radioprotection by polysaccharides alone and in combination with aminothiols, Adv Space Res., 1992, 12,233-248. DOI: 10.1016/0273-1177(92) 90113-C

13. Culy, C.R.; Spencer, C.M. Amifostine: an update on its clinical status as a cytoprotectant in patients with cancer receiving chemotherapy or radiotherapy and its potential therapeutic application in myelodysplastic syndrome, Drugs, 2001, 61,641-684.

14. Citrin, D.; Cotrim, A.P.; Hyodo, F.; Baum, B.J.; Krishna, M.C.; Mitchell, J.B. Radioprotectors and mitigators of radiationinduced normal tissue injury, Oncologist, 2010, 15,360-371. DOI: 10.1634/theoncologist.2009-S104

15. Hahn, S.M.; Tochner, Z.; Krishna, C.M.; Glass, J.; Wilson, L.; Samuni, A.; Sprague, M.; Venzon, D.; Glatstein, E.; Mitchell, J.B., et al. Tempol, a stable free radical, is a novel murine radiation protector, Cancer Res., 1992, 52,1750-1753.

16. Zhang, M.; Qian, J.; Xing, X.; Kong, F.-M.; Zhao, L.; Chen, M.; Lawrence, T.S. Inhibition of the Tumor Necrosis Factor- $\alpha$ Pathway Is Radioprotective for the Lung, Clin Cancer Res., 2008, 14,1868-1876. DOI: $\underline{\text { 10.1158/1078-0432.ccr-07-1894 }}$

17. Topkan, E.; Tufan, H.; Yavuz, A.A.; Bacanli, D.; Onal, C.; Kosdak, S.; Yavuz, M.N. Comparison of the protective effects of melatonin and amifostine on radiation-induced epiphyseal injury, Int J Radiat Biol., 2008, 84,796-802.

DOI: $10.1080 / 09553000802389678$

18. Gudkov, A.V.; Komarova, E.A. Radioprotection: smart games with death, $J$ Clin Invest., 2010, 120,2270-2273. DOI: $\underline{\text { 10.1172/JCI43794 }}$
19. Fedorocko, P.; Egyed, A.; Vacek, A. Irradiation induces increased production of haemopoietic and proinflammatory cytokines in the mouse lung, Int J Radiat Biol., 2002, 78,305-313.

DOI: 10.1080/09553000110104614

20. Leist, M.; Gantner, F.; Jilg, S.; Wendel, A. Activation of the $55 \mathrm{kDa}$ TNF receptor is necessary and sufficient for TNF-induced liver failure, hepatocyte apoptosis, and nitrite release, J Immunol., 1995, 154,1307-1316.

21. Ding, W.X.; Yin, X.M. Dissection of the multiple mechanisms of TNF-alpha-induced apoptosis in liver injury, $\mathrm{J}$ Cell Mol Med., 2004, 8,445-454. DOI: 10.1111/j.15824934.2004.tb00469.x

22. Shaw, J.; Chen, B.; Wooley, P.; Huang, W.-H.; Lee, A.-R.; Zeng, D. Anti-inflammatory and Anti-arthritic Effects of a Novel Leflunomide Analogue, UTL-5b (GBL-5b), Am J Biomed Sci., 2011, 3,31-39. DOI: 10.5099/aj110100031

23. Shaw, J.; Liu, C.; Martin, R.; Chen, B.; Holtz, R.; Huang, W.H.; Lee, A.R. Inhibition of tumour necrosis factor-alpha secretion from EpiDermTM tissues by a novel small molecule, UTL-5d, Br J Dermatol., 2007, 157,575-579. DOI: 10.1111/j.1365-2133.2007. $\underline{08025 . \mathrm{X}}$

24. Shaw, J.; Chen, B.; Huang, W.H.; Lee, A.R.; Media, J.; Valeriote, F.A. The small-molecule TNF-alpha modulator, UTL-5g, reduces side effects induced by cisplatin and enhances the therapeutic effect of cisplatin in vivo, $J$ Exp Ther Oncol., 2011, 9,129-137.

25. Choi, H.-k.; Kim, D.-h.; Kim, J.W.; Ngadiran, S.; Sarmidi, M.R.; Park, C.S. Labisia pumila extract protects skin cells from photoaging caused by UVB irradiation, J Biosci Bioeng., 2010, 109,291-296. DOI: 10.1016/j.jbiosc.2009.08.478

26. Bashir, M.; Sharma, M.; Werth, V. TNF- $\alpha$ production in the skin, Arch Dermatol Res., 2009, 301,87-91. DOI: 10.1007/s00403-0080893-7 